\title{
Processes regulating progressive nitrogen limitation under elevated carbon dioxide: a meta-analysis
}

\author{
Junyi Liang ${ }^{1}$, Xuan $\mathbf{Q i}^{1}$, Lara Souza ${ }^{1,2}$, and Yiqi Luo ${ }^{1,3}$ \\ ${ }^{1}$ Department of Microbiology and Plant Biology, University of Oklahoma, Norman, Oklahoma 73019, USA \\ ${ }^{2}$ Oklahoma Biological Survey, University of Oklahoma, Norman, Oklahoma 73019, USA \\ ${ }^{3}$ Center for Earth System Science, Tsinghua University, Beijing 100084, China \\ Correspondence to: Junyi Liang (jliangjn@gmail.com) and Yiqi Luo (yluo@ou.edu)
}

Received: 29 June 2015 - Published in Biogeosciences Discuss.: 20 October 2015

Revised: 20 April 2016 - Accepted: 27 April 2016 - Published: 10 May 2016

\begin{abstract}
The nitrogen $(\mathrm{N})$ cycle has the potential to regulate climate change through its influence on carbon (C) sequestration. Although extensive research has explored whether or not progressive $\mathrm{N}$ limitation (PNL) occurs under $\mathrm{CO}_{2}$ enrichment, a comprehensive assessment of the processes that regulate PNL is still lacking. Here, we quantitatively synthesized the responses of all major processes and pools in the terrestrial $\mathrm{N}$ cycle with meta-analysis of $\mathrm{CO}_{2}$ experimental data available in the literature. The results showed that $\mathrm{CO}_{2}$ enrichment significantly increased $\mathrm{N}$ sequestration in the plant and litter pools but not in the soil pool, partially supporting one of the basic assumptions in the PNL hypothesis that elevated $\mathrm{CO}_{2}$ results in more $\mathrm{N}$ sequestered in organic pools. However, $\mathrm{CO}_{2}$ enrichment significantly increased the $\mathrm{N}$ influx via biological $\mathrm{N}$ fixation and the loss via $\mathrm{N}_{2} \mathrm{O}$ emission, but decreased the $\mathrm{N}$ efflux via leaching. In addition, no general diminished $\mathrm{CO}_{2}$ fertilization effect on plant growth was observed over time up to the longest experiment of 13 years. Overall, our analyses suggest that the extra $\mathrm{N}$ supply by the increased biological $\mathrm{N}$ fixation and decreased leaching may potentially alleviate PNL under elevated $\mathrm{CO}_{2}$ conditions in spite of the increases in plant $\mathrm{N}$ sequestration and $\mathrm{N}_{2} \mathrm{O}$ emission. Moreover, our syntheses indicate that $\mathrm{CO}_{2}$ enrichment increases soil ammonium $\left(\mathrm{NH}_{4}^{+}\right)$to nitrate $\left(\mathrm{NO}_{3}^{-}\right)$ratio. The changed $\mathrm{NH}_{4}^{+} / \mathrm{NO}_{3}^{-}$ratio and subsequent biological processes may result in changes in soil microenvironments, above-belowground community structures and associated interactions, which could potentially affect the terrestrial biogeochemical cycles. In addition, our data synthesis suggests that more long-term studies, especially in regions other than
\end{abstract}

temperate ones, are needed for comprehensive assessments of the PNL hypothesis.

\section{Introduction}

Fossil-fuel burning and deforestation have led to substantial increase in atmospheric carbon dioxide $\left(\mathrm{CO}_{2}\right)$ concentrations, which could stimulate plant growth (IPCC, 2013). The plant growth stimulated by $\mathrm{CO}_{2}$ fertilization and the resulting terrestrial carbon (C) storage could partially mitigate the further increase in $\mathrm{CO}_{2}$ concentrations and associated climate warming (IPCC, 2013). However, this effect may be constrained by the availability of nitrogen $(\mathrm{N})$, an essential element for molecular compounds of amino acids, proteins, ribonucleic acids (RNAs) and deoxyribonucleic acids (DNAs) in organisms (Rastetter et al., 1997; Oren et al., 2001; Luo et al., 2004; Reich et al., 2006; Norby et al., 2010; Reich and Hobbie, 2013). A popular hypothesis of the $\mathrm{N}$ constraint to the $\mathrm{CO}_{2}$ fertilization effect is progressive $\mathrm{N}$ limitation (PNL) (Luo et al., 2004).

Progressive $\mathrm{N}$ limitation postulates that the stimulation of plant growth by $\mathrm{CO}_{2}$ enrichment results in more $\mathrm{N}$ sequestered in plant, litter and soil organic matter (SOM) so that the $\mathrm{N}$ availability for plant growth progressively declines in soils over time (Luo et al., 2004). The reduced $\mathrm{N}$ availability then in turn constrains the further $\mathrm{CO}_{2}$ fertilization effect on plant growth over longer timescales. However, whether and to what extent PNL occurs depends on the balance of $\mathrm{N}$ demand and supply (Luo et al., 2004; Finzi et al., 2006; Walker et al., 2015). If the $\mathrm{N}$ supply meets the $\mathrm{N}$ de- 
mand, PNL may not occur. Otherwise, PNL may lead to a diminished $\mathrm{CO}_{2}$ fertilization effect on plant growth over time. Some of the site-level studies support (Reich et al., 2006; Norby et al., 2010), while the others refute the PNL hypothesis (Finzi et al., 2006; Moore et al., 2006). To date, no general pattern of PNL across ecosystems has yet been revealed.

Since the key determining PNL occurrence is whether N supply meets $\mathrm{N}$ demand (Luo et al., 2004), it is important to understand how $\mathrm{N}$ supply changes under elevated $\mathrm{CO}_{2}$. The change in the $\mathrm{N}$ supply for plant growth under elevated $\mathrm{CO}_{2}$ is determined by the responses of multiple $\mathrm{N}$ cycling processes, including biological $\mathrm{N}$ fixation, mineralization, nitrification, denitrification, and leaching (Chapin III et al., 2011). In addition, the responses of these processes to $\mathrm{CO}_{2}$ enrichment may be influenced by external $\mathrm{N}$ addition, such as $\mathrm{N}$ deposition and fertilization (Reay et al., 2008). Thus, synthesizing the responses of processes that regulate PNL to $\mathrm{CO}_{2}$ enrichment may help reveal the general pattern of PNL in terrestrial ecosystems.

In the current study, the main objective was to synthesize data published in the literature on the $\mathrm{N}$ limitation to plant growth under enriched $\mathrm{CO}_{2}$ conditions. Our data synthesis was designed to answer two questions: (i) how do the major processes in the terrestrial $\mathrm{N}$ cycle respond to $\mathrm{CO}_{2}$ enrichment? (ii) Does the $\mathrm{CO}_{2}$ fertilization effect on plant growth diminish over time? To answer these questions, two sets of data from the literature were collected (Supplement Table S1, Table 1). With the first data set, we quantitatively examined the effects of $\mathrm{CO}_{2}$ enrichment on all the major processes and pools in the $\mathrm{N}$ cycle using meta-analysis. These processes and pools included $\mathrm{N}$ sequestered in organic components (i.e., plant tissues, litter and soil organic matter (SOM)), biological $\mathrm{N}$ fixation, net mineralization, nitrification, denitrification, leaching, and total inorganic N (TIN), ammonium $\left(\mathrm{NH}_{4}^{+}\right)$and nitrate $\left(\mathrm{NO}_{3}^{-}\right)$contents in soils. We separated the first data set according to the experimental durations to explore the responses of the $\mathrm{N}$ processes to short- vs. long-term $\mathrm{CO}_{2}$ treatments. In addition, the responses of the $\mathrm{N}$ processes to $\mathrm{CO}_{2}$ enrichment were compared between without and with $\mathrm{N}$ addition conditions. The second data set was compiled for the plant growth in decadal free air $\mathrm{CO}_{2}$ enrichment (FACE) experiments. With the data set, we explored whether the $\mathrm{CO}_{2}$ fertilization effect on plant growth diminishes or not over time.

\section{Materials and methods}

\subsection{Data collection}

For the first data set, a comprehensive literature search with the terms of " $\mathrm{CO}_{2}$ enrichment (or $\mathrm{CO}_{2}$ increase)", "nitrogen" and "terrestrial" was conducted using the online search connection Web of Science in Endnote. Then, papers meeting the following two criteria were selected to do the fur- ther analyses: (i) including both control and $\mathrm{CO}_{2}$ enrichment treatments, where the ambient and elevated $\mathrm{CO}_{2}$ concentrations were around the current and predicted atmospheric $\mathrm{CO}_{2}$ concentrations by the Intergovernmental Panel on Climate Change (IPCC, 2013), respectively (Fig. S1 in the Supplement); (ii) including or from which we could calculate at least one of the major $\mathrm{N}$ pools or processes: soil TIN content, soil $\mathrm{NH}_{4}^{+}$content, soil $\mathrm{NO}_{3}^{-}$content, aboveground plant $\mathrm{N}$ pool (APNP), belowground plant N pool (BPNP), total plant $\mathrm{N}$ pool (TPNP), litter N pool (LNP), soil N pool (SNP), $\mathrm{N}$ fixation, nodule mass and/or number, net mineralization, nitrification, denitrification, and inorganic $\mathrm{N}$ leaching. Overall, there were 175 papers included in the first data set (Table S1, References S1). For each paper, means, variations (standard deviation (SD), standard error (SE) or confidence interval (CI)) and sample sizes of the variables in both control and $\mathrm{CO}_{2}$ enrichment treatments were collected.

For those studies that provided SE or CI, SD was computed by

$\mathrm{SD}=\mathrm{SE} \sqrt{n}$

or $\mathrm{SD}=\left(\mathrm{CI}_{\mathrm{u}}-\mathrm{CI}_{1}\right) \sqrt{n} / 2 u_{P}$,

where $n$ is the sample size, $\mathrm{CI}_{\mathrm{u}}$ and $\mathrm{CI}_{1}$ are the upper and lower limits of CI, and $u_{P}$ is the significant level and equal to 1.96 and 1.645 when $\alpha=0.05$ and 0.10 , respectively. In some studies, if tissue $\mathrm{N}$ concentration and biomass were reported, we multiplied the two parts as N pools. When both APNP and BPNP were provided (or calculated), the two were added together to represent the TPNP. When data from multiple soil layers were provided, they were summed if they were area-based (i.e., $\mathrm{m}^{-2}$ land), or averaged if they were weightbased (i.e., $\mathrm{g}^{-1}$ soil). In studies where the respective contents of $\mathrm{NH}_{4}^{+}$and $\mathrm{NO}_{3}^{-}$were reported, the TIN was calculated by adding the two together. For all the variables, if more than one result were reported during the experiment period, they were averaged by

$M=\sum_{i=1}^{j} \frac{M_{i}}{j}$

with standard deviation

$\mathrm{SD}=\sqrt{\frac{\sum_{i=1}^{j} \mathrm{SD}_{i}^{2}\left(n_{i}-1\right) n_{i}}{\left(\sum_{i=1}^{j} n_{i}-1\right) \sum_{i=1}^{j} n_{i}}}$,

where $j$ is the number of results, $M_{i}, \mathrm{SD}_{i}$ and $n_{i}$ are the mean, SD and sample size of the $i$ th sampling data, respectively (Liang et al., 2013). If additional treatments applied (e.g., $\mathrm{N}$ addition), they were treated as independent studies.

Because treatment time and $\mathrm{N}$ addition may affect the responses of the $\mathrm{N}$ processes to $\mathrm{CO}_{2}$ enrichment, the data set was divided into different categories: (i) short-term ( $\leq 3$ years) vs. long-term ( $>3$ years), and (ii) without $\mathrm{N}$ addition vs. with $\mathrm{N}$ addition. Moreover, the data set was also 
Table 1. Results on the effect of $\mathrm{CO}_{2}$ enrichment on ecosystem NPP (or biomass or leaf production) in decadal free air $\mathrm{CO}_{2}$ enrichment (FACE) experiments over treatment time. The values of the slope, $R^{2}$ and $P$ in the linear regression in Fig. 4 are shown. The lower and upper n (i.e., $n$ and N) in Refs. Schneider et al. (2004), McCarthy et al. (2010) and Reich and Hobbie (2013) mean without and with N addition, respectively. The lower and upper o (i.e., o and O) in Ref. Talhelm et al. (2012) mean without and with $\mathrm{O}_{3}$ treatment, respectively.

\begin{tabular}{llrlrlll}
\hline Experiment & Ecosystem type & Treatment years & Variable & Slope & $R^{2}$ & $P$ & Reference \\
\hline Duke_n & Forest & 8 & NPP & 0.50 & 0.25 & 0.21 & McCarthy et al. (2010) \\
Duke_N & Forest & 8 & NPP & -1.39 & 0.27 & 0.29 & McCarthy et al. (2010) \\
ORNL & Forest & 11 & NPP & -1.42 & 0.38 & 0.04 & Norby et al. (2010) \\
BioCON_n & Grassland & 13 & Biomass & 0.42 & 0.05 & 0.48 & Reich and Hobbie (2013) \\
BioCON_N & Grassland & 13 & Biomass & 0.23 & 0.01 & 0.76 & Reich and Hobbie (2013) \\
NZ & Grassland & 10 & Biomass & 0.95 & 0.05 & 0.53 & Ross et al. (2013) \\
Swiss_n & Grassland & 10 & Harvestable biomass & 0.30 & 0.01 & 0.75 & Schneider et al. (2004) \\
Swiss_N & Grassland & 10 & Harvestable biomass & 1.66 & 0.47 & 0.03 & Schneider et al. (2004) \\
NDFF & Desert & 9 & Standing biomass & -9.54 & 0.15 & 0.40 & Smith et al. (2014) \\
Aspen_o & Forest & 7 & Leaf production & -0.07 & 0.00 & 0.97 & Talhelm et al. (2012) \\
Aspen_O & Forest & 7 & Leaf production & 0.09 & 0.00 & 0.93 & Talhelm et al. (2012) \\
AspenBirch_o & Forest & 7 & Leaf production & -5.27 & 0.77 & 0.01 & Talhelm et al. (2012) \\
AspenBirch_O & Forest & 7 & Leaf production & 6.48 & 0.82 & 0.00 & Talhelm et al. (2012) \\
AspenMaple_o & Forest & 7 & Leaf production & -9.16 & 0.40 & 0.13 & Talhelm et al. (2012) \\
AspenMaple_O & Forest & 7 & Leaf production & 1.11 & 0.11 & 0.46 & Talhelm et al. (2012) \\
\hline
\end{tabular}

divided into forest, grassland, and cropland to explore possible differences between ecosystem types.

For the second data set, 15 available time series of plant growth were collected from 7 decadal FACE experiments (Table 1). The ecosystems included nine forests, five grasslands and one desert. Because of the limited data, we included variables that can represent plant growth in one way or another, for example, net primary production (NPP), biomass, and leaf production. These data were collected to reveal whether the effect of $\mathrm{CO}_{2}$ enrichment on plant growth diminishes over treatment time as proposed by the PNL hypothesis (Luo et al., 2004). In the seven studies, the treatment lasted from 7 to 13 years, and at least 6 years' production measurements were reported. For each data, the percentage change in NPP (or biomass or leaf production) by $\mathrm{CO}_{2}$ enrichment was calculated. Then, a linear regression between the percentage change and the treatment year was conducted. A significantly negative slope indicates that the effect of $\mathrm{CO}_{2}$ enrichment on the plant production diminishes over time. A non-significant slope was treated as 0 . After deriving all the slopes, the frequency distribution of the slopes were fitted by a Gaussian function:

$y=y 0+a e^{-\frac{(x-\mu)^{2}}{2 \sigma^{2}}}$,

where $x$ is the mean value of each individual interval, and $y$ is the frequency of each interval. $y 0$ is the base frequency. $\mu$ and $\sigma$ are the mean and SD of the distribution.

\subsection{Meta-analysis}

With the first data set, the effect of $\mathrm{CO}_{2}$ enrichment for each line of data of the $\mathrm{N}$ variables was estimated using the natu- ral logarithm transformed response ratio (RR) (Hedges et al., 1999; Liang et al., 2013):

$\log _{e} \mathrm{RR}=\log _{e}\left(X_{\mathrm{E}} / X_{\mathrm{C}}\right)$,

where $X_{\mathrm{E}}$ and $X_{\mathrm{C}}$ are the variable values under enriched $\mathrm{CO}_{2}$ and control conditions, respectively. The variation of the $\log$ RR was

$V=\left(\frac{\mathrm{SD}_{\mathrm{C}}^{2}}{n_{\mathrm{C}} X_{\mathrm{C}}^{2}}+\frac{\mathrm{SD}_{\mathrm{E}}^{2}}{n_{\mathrm{E}} X_{\mathrm{E}}^{2}}\right)$,

where $\mathrm{SD}_{\mathrm{C}}$ and $\mathrm{SD}_{\mathrm{E}}$ are the standard deviation of $X_{\mathrm{C}}$ and $X_{\mathrm{E}}$, and $n_{\mathrm{C}}$ and $n_{\mathrm{E}}$ are the sample sizes of $X_{\mathrm{C}}$ and $X_{\mathrm{E}}$.

Then, the random-effects model was used to calculate the weighted mean. In the random-effects model, the weighted mean was calculated as

$M_{\text {weighted }}=\frac{\sum_{j=1}^{k} W_{j}^{*} M_{j}}{\sum_{j=1}^{k} W_{j}^{*}}$

with the variance as

$V_{\text {weighted }}=\frac{1}{\sum_{j=1}^{k} W_{j}^{*}}$,

where $k$ is the number of studies, $M_{j}$ is the $\operatorname{Ln}(\mathrm{RR})$ in study $j$, and $W_{j}^{*}$ is the weighting factor which consists of betweenand within-study variances (Rosenberg et al., 2000; Liang et al., 2013). The $95 \%$ lower and upper limits ( $\mathrm{LL}_{\text {weighted }}$ and $\mathrm{UL}_{\text {weighted}}$ ) for the weighted mean were computed as

$\mathrm{LL}_{\text {weighted }}=M_{\text {weighted }}-1.96 \times \sqrt{V_{\text {weighted }}}$ 
and

$\mathrm{UL}_{\text {weighted }}=M_{\text {weighted }}+1.96 \times \sqrt{V_{\text {weighted }}}$.

The weighted mean and corresponding $95 \%$ bootstrapping CI (999 iterations) for each variable and category were calculated in MetaWin 2.1 (details are described in the software handbook by Rosenberg et al., 2000). The results were back-transformed and represented as percentage change by $(\mathrm{RR}-1) \times 100 \%$. The response was considered significant if the $95 \%$ CI did not overlap with zero.

\section{Results}

The meta-analysis of the first data set showed that $\mathrm{CO}_{2}$ enrichment significantly increased $\mathrm{N}$ sequestered in plants and litter but not in SOM (Figs. 1a, S2). Whereas $\mathrm{CO}_{2}$ enrichment had little overall effects on $\mathrm{N}$ mineralization, nitrification and denitrification, it significantly increased biological $\mathrm{N}$ fixation by $44.3 \%$ (with $95 \%$ CI from 29.5 to $61.8 \%$ ). The increased biological $\mathrm{N}$ fixation was consistent when using various methods except $\mathrm{H}_{2}$ evolution (Fig. 2a). In legume species, $\mathrm{CO}_{2}$ enrichment significantly increased nodule mass and number (Fig. 2b). In addition, $\mathrm{CO}_{2}$ enrichment increased $\mathrm{N}_{2} \mathrm{O}$ emission by $10.7 \%$ (with $95 \% \mathrm{CI}$ from 2.0 to $22.3 \%$ ), but reduced leaching (i.e., -41.8 with $95 \% \mathrm{CI}$ from -58.9 to $-24.3 \%$ ) (Fig. 1b). Although $\mathrm{CO}_{2}$ enrichment did not change the total inorganic $\mathrm{N}$ availability in soils, it increased the soil $\mathrm{NH}_{4}^{+} / \mathrm{NO}_{3}^{-}$ratio by $16.9 \%$ (with $95 \% \mathrm{CI}$ from 5.4 to $30.2 \%$ ) (Fig. 1c).

Treatment time had no effect on most of the variables (overlapped $95 \%$ CIs for short- and long-term treatments) except nitrification, which was not changed by short-term treatment, but was significantly reduced $(-23.4$ with $95 \%$ $\mathrm{CI}$ from -30.4 to $-12.1 \%$ ) by long-term $\mathrm{CO}_{2}$ enrichment (Fig. 3b). In addition, it seemed that the responses of the $\mathrm{NH}_{4}^{+} / \mathrm{NO}_{3}^{-}$ratio was strengthened over time, representing a neutral response to short-term $\mathrm{CO}_{2}$ enrichment, but significantly positive and negative responses to long-term $\mathrm{CO}_{2}$ enrichment (Fig. 3c). The effects of $\mathrm{CO}_{2}$ enrichment were influenced by $\mathrm{N}$ addition (Fig. 3d-f). For example, nitrification was significantly reduced by $\mathrm{CO}_{2}$ enrichment without $\mathrm{N}$ addition by $19.3 \%$ (with $95 \% \mathrm{CI}$ from -40.5 to $-0.65 \%$ ), but was not changed with $\mathrm{N}$ addition. Denitrification and $\mathrm{N}_{2} \mathrm{O}$ emission responded to $\mathrm{CO}_{2}$ enrichment neutrally without $\mathrm{N}$ addition, but significantly positively with $\mathrm{N}$ addition (Fig. 3e). Additionally, the responses of some variables to $\mathrm{CO}_{2}$ enrichment were dependent on ecosystem type (Fig. 3g-i). APNP responded to $\mathrm{CO}_{2}$ enrichment positively in forests and croplands, but neutrally in grasslands (Fig. $3 \mathrm{~g}$ ). Net mineralization had no response to $\mathrm{CO}_{2}$ enrichment in forests or grasslands, while it was significantly increased in croplands (Fig. 3h). Moreover, the change in the TIN was neutral in forests, grassland, but positive, in croplands, re-

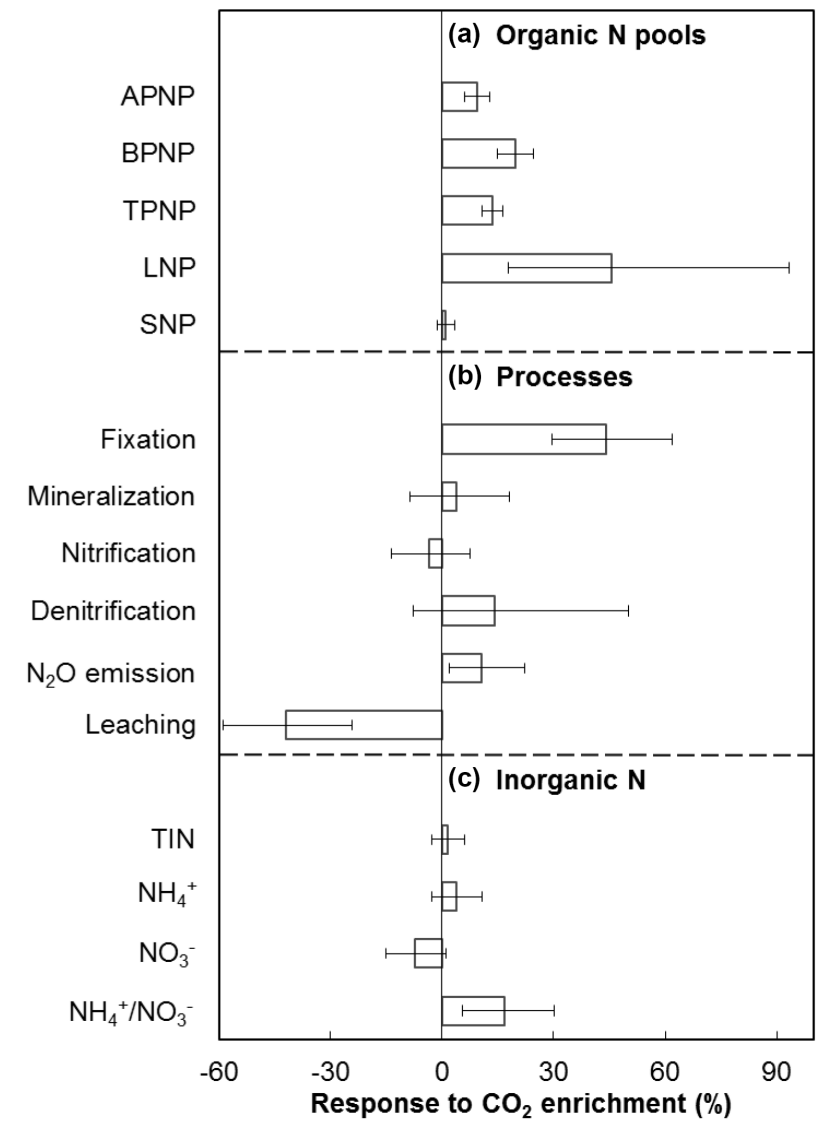

Figure 1. Results of a meta-analysis on the responses of nitrogen pools and processes to $\mathrm{CO}_{2}$ enrichment. In (a), APNP, BPNP, TPNP, LNP, and SNP are the abbreviations for aboveground plant nitrogen pool, belowground plant nitrogen pool, total plant nitrogen pool, litter nitrogen pool, and soil nitrogen pool, respectively. In (c), TIN, $\mathrm{NH}_{4}^{+}$and $\mathrm{NO}_{3}^{-}$are total inorganic nitrogen, ammonium, and nitrate in soils, respectively. The error bars represent $95 \%$ confidence intervals.

spectively (Fig. 3i). In addition, a positive response of the $\mathrm{NH}_{4}^{+} / \mathrm{NO}_{3}^{-}$ratio was only observed in grasslands (Fig. 3i).

The results from the second data set showed that $\mathrm{CO}_{2}$ enrichment significantly increased plant growth in most of the decadal FACE experiments (Fig. 4). In addition, the $\mathrm{CO}_{2}$ fertilization effect on plant growth did not over treatment time change in 11 experiments $(P>0.05)$, decreased in 2 experiments (slope $<0, P<0.05$ ), and increased in 2 experiments (slope $>0, P<0.05$ ), respectively (Table 1, Fig. 4). Overall, the slope of the response of the plant growth vs. treatment time was not significantly different from 0 (i.e., $-0.37 \%$ year $^{-1}$ with $95 \%$ CI from -1.84 to $1.09 \%$ year $^{-1}$; Fig. 4). 


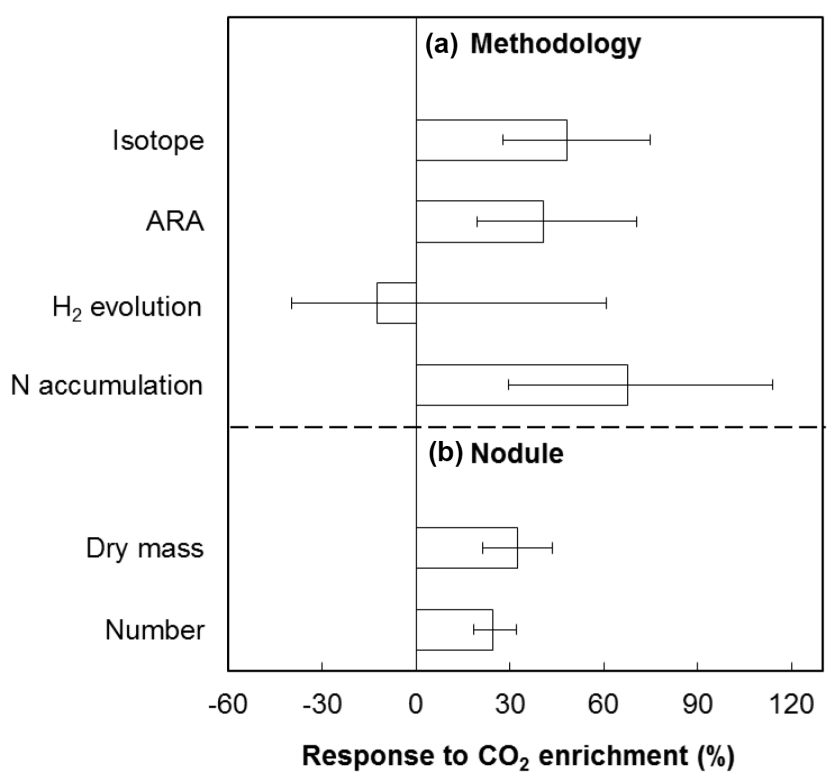

Figure 2. Responses of biological N fixation measured by different methods (a) and nodule dry mass and number in legume species (b). ARA: acetylene reduction assay. Mean $\pm 95 \%$ confidence interval.

\section{Discussion}

In this study, we carried out two syntheses on the responses of the terrestrial $\mathrm{N}$ cycle and plant growth to $\mathrm{CO}_{2}$ enrichment to test whether PNL generally occurs across ecosystems.

\subsection{PNL alleviation}

According to the PNL hypothesis, a prerequisite for PNL occurrence is that more $\mathrm{N}$ is sequestered in plant, litter and SOM (Luo et al., 2004). Our results showed that elevated $\mathrm{CO}_{2}$ significantly increased $\mathrm{N}$ retention in plant tissues and litter, which is consistent with previous meta-analyses (de Graaff et al., 2006; Luo et al., 2006). Thus, there seems to be evidence for some basic assumptions of the PNL hypothesis. However, the results from the second data set did not show a general diminished $\mathrm{CO}_{2}$ fertilization effect on plant growth on the decadal scale, which disagrees with the expectation of the PNL hypothesis, suggesting that $\mathrm{N}$ supply under elevated $\mathrm{CO}_{2}$ may meet the $\mathrm{N}$ demand. In this study, we have identified two processes that increase $\mathrm{N}$ supply under elevated $\mathrm{CO}_{2}$, i.e., biological $\mathrm{N}$ fixation and leaching.

$\mathrm{CO}_{2}$ enrichment significantly enhanced the $\mathrm{N}$ influx to terrestrial ecosystems through biological $\mathrm{N}$ fixation, which reduces dinitrogen $\left(\mathrm{N}_{2}\right)$ to $\mathrm{NH}_{4}^{+}$(Fig. 1b). The enhanced biological $\mathrm{N}$ fixation may have resulted from the stimulated activities of symbiotic (Fig. 2b) and free-living heterotrophic $\mathrm{N}$-fixing bacteria (Hoque et al., 2001). In addition, the competition between $\mathrm{N}_{2}$-fixing and non- $\mathrm{N}_{2}$-fixing species may have contributed to enhancing the biological $\mathrm{N}$ fixation at the ecosystem level (Poorter and Navas, 2003; Batterman et al., 2013).

In addition, the $\mathrm{N}$ efflux via leaching was reduced under elevated $\mathrm{CO}_{2}$ conditions (Fig. 1b). This could be attributed to the decrease in $\mathrm{NO}_{3}^{-}$, which is the primary $\mathrm{N}$ form in leaching, (Chapin III et al., 2011), and the increased root growth which may immobilize more inorganic $\mathrm{N}$ in soils (Luo et al., 2006; Iversen, 2010). In contrast, gaseous $\mathrm{N}$ loss through $\mathrm{N}_{2} \mathrm{O}$ emission increased under elevated $\mathrm{CO}_{2}$, although this increase was only observed when additional $\mathrm{N}$ was applied.

The net effect of the responses of $\mathrm{N}$ processes to $\mathrm{CO}_{2}$ enrichment resulted in higher $\mathrm{N}$ retention in ecosystems, especially within plant tissues and litter (Fig. S2). Because the product of biological $\mathrm{N}$ fixation (i.e., $\mathrm{NH}_{4}^{+}$) and the primary form for $\mathrm{N}$ leaching loss (i.e., $\mathrm{NO}_{3}^{-}$) can be directly used by plants, the effects of $\mathrm{CO}_{2}$ enrichment on the two processes directly increase the $\mathrm{N}$ availability for plant growth, potentially alleviating PNL (Fig. 5). The increased $\mathrm{N}$ in plant tissues can be re-used by plants via resorption (Norby et al., 2000, 2001), and consequently reduce the $\mathrm{N}$ demand from soils. This may be another mechanism that alleviates PNL (Walker et al., 2015). Therefore, the increased $\mathrm{N}$ availability from increased $\mathrm{N}$ fixation and reduced $\mathrm{N}$ leaching could potentially support net accumulation of organic matter in terrestrial ecosystems (Rastetter et al., 1997; Luo and Reynolds, 1999).

Since biological $\mathrm{N}$ fixation provides at least $30 \%$ of the $\mathrm{N}$ requirement across natural biomes (Asner et al., 2001; Galloway et al., 2004), our results suggest that the positive response of biological $\mathrm{N}$ fixation to $\mathrm{CO}_{2}$ enrichment plays an important role in alleviating PNL. The PNL hypothesis was proposed to characterize long-term dynamics of C$\mathrm{N}$ coupling in response to rising atmospheric $\mathrm{CO}_{2}$ concentration. Thus, it is critical to understand the long-term response of biological $\mathrm{N}$ fixation to elevated $\mathrm{CO}_{2}$. In this paper, we have synthesized 12 studies that lasted 4-7 years and binned them in a long-term category ( $>3$ years). On average, in those long-term studies, $\mathrm{CO}_{2}$ enrichment increased biological $\mathrm{N}$ fixation by $26.2 \%$. The increased biological $\mathrm{N}$ fixation is supported by evidence at gene level from longterm experiments. For example, Tu et al. (2016) found that the abundance of nif $\mathrm{H}$ gene amplicons, which is a widely used marker for analysing biological $\mathrm{N}$ fixation, was significantly enhanced by 12 years of $\mathrm{CO}_{2}$ enrichment in a grassland (BioCON). However, our synthesis showed a relatively wide $95 \%$ confidence interval from 2.54 to $59.8 \%$. The wide range can be partially attributed to the relatively small number of studies. In addition, most studies incorporated in the current synthesis were conducted in temperate regions. Thus, longer-term studies, as well as studies in other regions (e.g., boreal and tropical) are critically needed to reveal more general patterns in the future.

In this study, it is suggested that the general trend of the $\mathrm{N}$ cycle changes under elevated $\mathrm{CO}_{2}$ converges towards in- 


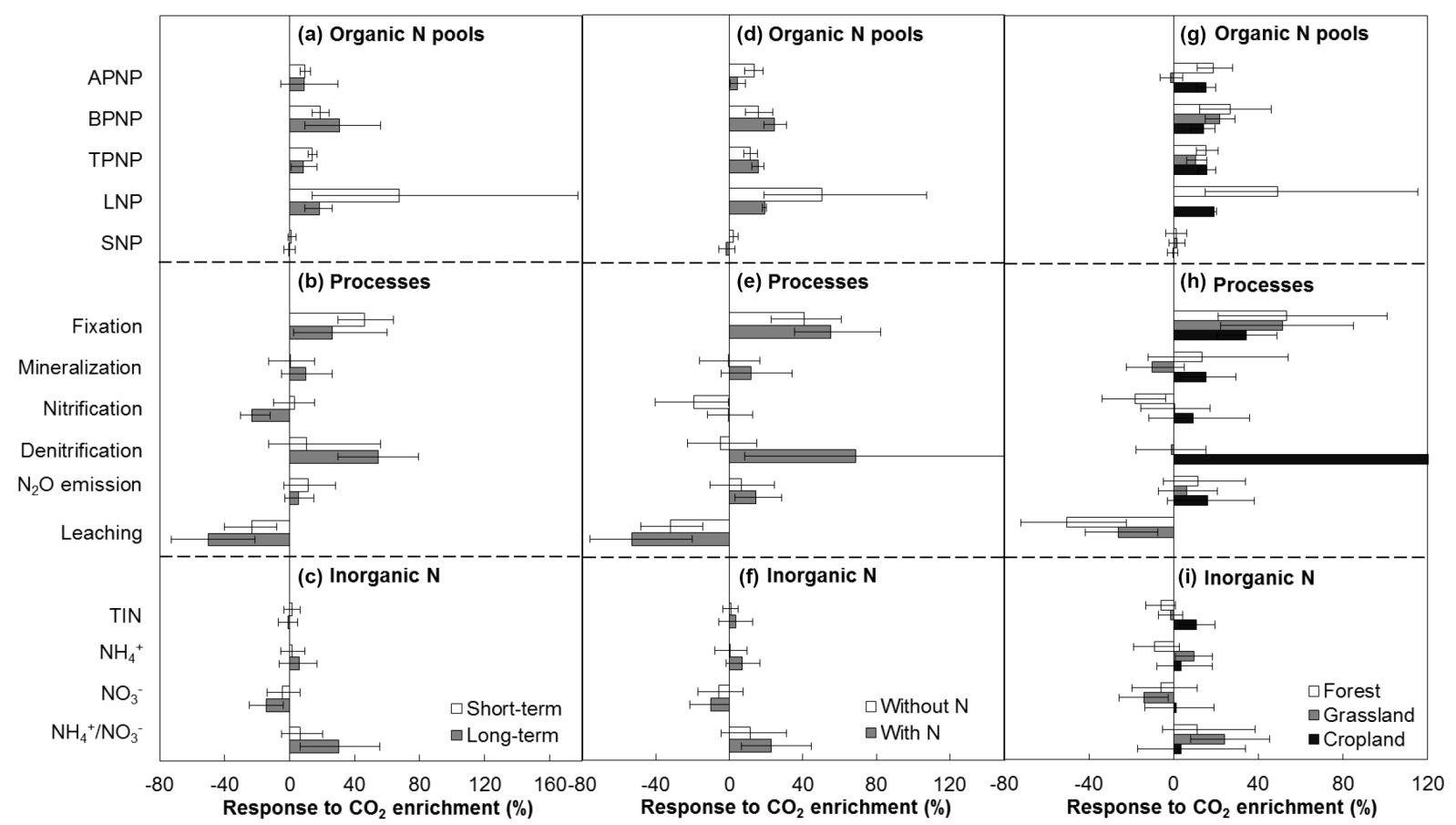

Figure 3. Responses of terrestrial nitrogen pools and processes to $\mathrm{CO}_{2}$ enrichment (Mean $\pm 95 \%$ confidence interval) as regulated by experimental durations (a-c; short-term: $\leq 3$ years vs. long-term: $>3$ years), nitrogen addition (d-f), and ecosystem types (g-i). Please see Fig. 1 for abbreviations.

creased soil $\mathrm{N}$ supply for plant growth, which in theory could alleviate PNL. However, the PNL alleviation potential may vary across different ecosystems due to asymmetric distributions of biological $\mathrm{N}$ fixation (Cleveland et al., 1999). In addition, PNL alleviation may also be influenced by other factors. While a diminished $\mathrm{CO}_{2}$ fertilization effect on plant growth was not observed in most of the long-term experiments, it occurred in two sites (i.e., ORNL and Aspen-Birch) (Fig. 4). Plant growth is usually influenced by multiple environmental factors (e.g., nutrients, water, light, ozone). The undiminished $\mathrm{CO}_{2}$ fertilization effect in most studies indicates that resource limitation (including $\mathrm{N}$ ) was not aggravated, suggesting that no PNL occurred in these sites. However, in the ORNL and Aspen-Birch (without $\mathrm{O}_{3}$ treatment) experiments, the diminished $\mathrm{CO}_{2}$ fertilization effect on plant growth was potentially driven by limitation of $\mathrm{N}$, or other resources, or their combined effect. For example, reduced $\mathrm{N}$ availability has been identified as one of the primary factors that lead to the diminished $\mathrm{CO}_{2}$ fertilization effect on NPP in the ORNL FACE experiment (Norby et al., 2010). In the Aspen-Birch community, however, the deceleration of leaf area increases due to canopy closure was responsible for the diminished $\mathrm{CO}_{2}$ fertilization effect on plant growth without $\mathrm{O}_{3}$ addition (Talhelm et al., 2012). With $\mathrm{O}_{3}$ addition, $\mathrm{O}_{3}$ significantly reduced the canopy development, resulting in a relatively open canopy during the experiment period. In addition, the negative effect of $\mathrm{O}_{3}$ addition increased over time, leading to the apparent increase in the $\mathrm{CO}_{2}$ fertilization effect (Fig. 4) (Talhelm et al., 2012).

\subsection{Dependence of the responses of $\mathbf{N}$ cycling processes upon methodology, treatment duration, $\mathrm{N}$ addition and ecosystem types}

Experimental methodology may potentially influence findings. Cabrerizo et al. (2001) found that $\mathrm{CO}_{2}$ enrichment increased the nitrogenase activity measured by acetylene reduction assay (ARA), but not the specific $\mathrm{N}$ fixation measured by the $\mathrm{H}_{2}$ evolution method. In the studies synthesized here, four methods were used to estimate biological $\mathrm{N}$ fixation, including isotope, ARA, $\mathrm{H}_{2}$ evolution and $\mathrm{N}$ accumulation. Among them, ARA and $\mathrm{H}_{2}$ evolution measure nitrogenase activity (Hunt and Layzell, 1993), whereas isotope and $\mathrm{N}$ accumulation methods directly measure biological $\mathrm{N}$ fixation. All but the $\mathrm{H}_{2}$ evolution method showed a significantly positive response to $\mathrm{CO}_{2}$ enrichment (Fig. 2a). The insignificant response shown by the $\mathrm{H}_{2}$ evolution method was likely because of the small study numbers (i.e., 3 ). In addition, the biological $\mathrm{N}$ fixation measured by ARA, isotope and $\mathrm{N}$ accumulation showed similar response magnitudes (Fig. 2a), suggesting consistency among the three methods. However, further assessment on the $\mathrm{H}_{2}$ evolution method is needed.

The responses of some $\mathrm{N}$ cycling processes that affect $\mathrm{N}$ availability are dependent on treatment duration, $\mathrm{N}$ addition, and/or ecosystem types (Fig. 3). 

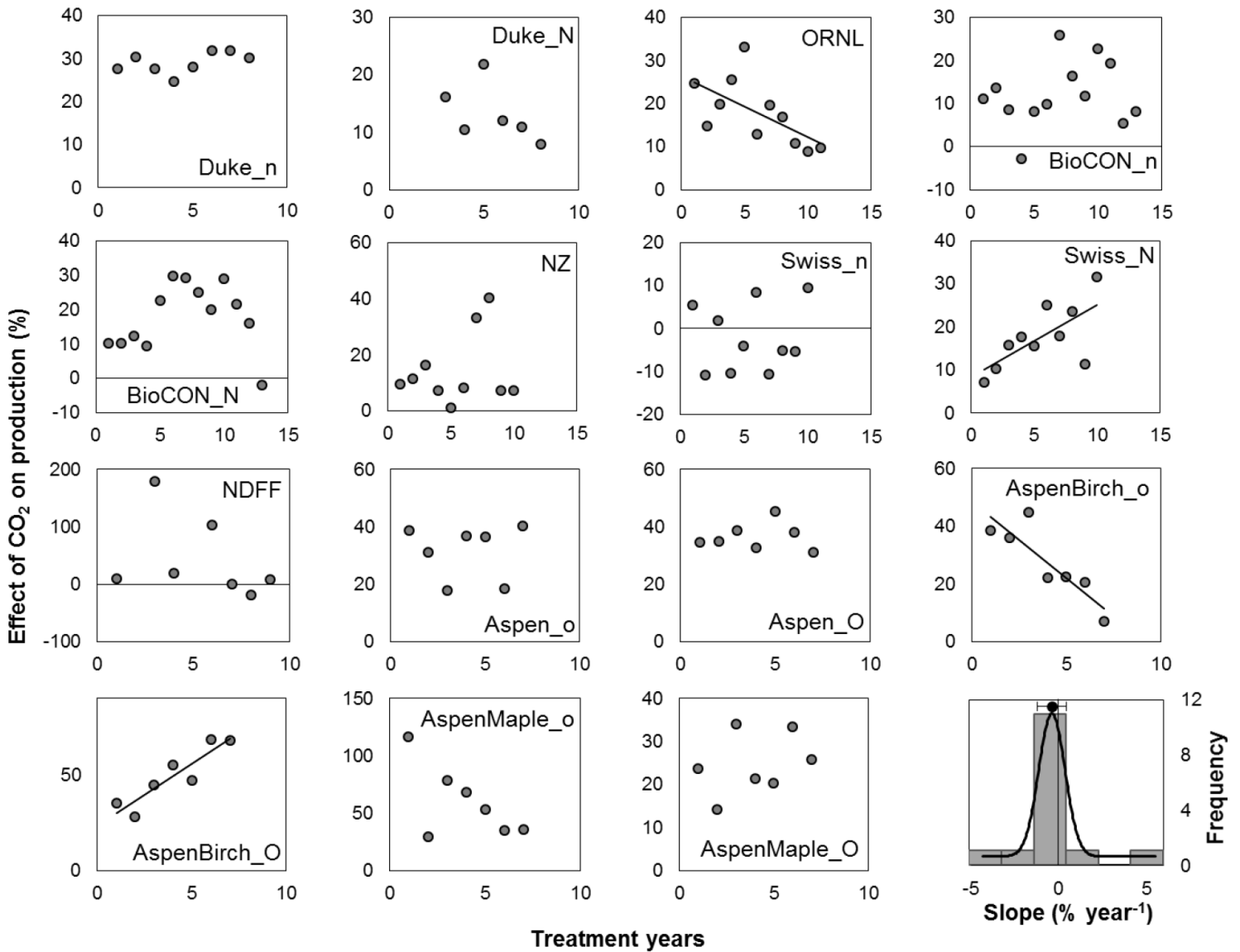

Figure 4. Time courses of $\mathrm{CO}_{2}$ effects on ecosystem NPP (or biomass or leaf production) in decadal-long FACE experiments. Please see Table 1 for details of experiments, references and statistical results. Only statistically significant $(P<0.05)$ regression lines are shown. The panel at the right-low corner shows the distribution of the slopes $\left(-0.37 \%\right.$ year $^{-1}$ with $95 \%$ CI from -1.84 to $1.09 \%$ year $\left.{ }^{-1}\right)$.

$\mathrm{N}$ mineralization, in addition to biological $\mathrm{N}$ fixation, is a major source of available $\mathrm{N}$ in soils. Our meta-analysis showed no change in the net $\mathrm{N}$ mineralization in response to $\mathrm{CO}_{2}$ enrichment, which is consistent with the results by de Graaff et al. (2006). However, the response of net mineralization was dependent upon ecosystem types, showing no change in forests and grasslands, but significant increases in croplands (Fig. 3h). There may be two reasons for the stimulated net mineralization in croplands. First, $\mathrm{N}$ fertilization, which is commonly practiced in croplands, can increase the substrate quantity and quality for mineralization (Barrios et al., 1996; Chapin III et al., 2011; Booth et al., 2005; Lu et al., 2011; Reich and Hobbie, 2013). Second, tillage can alter soil conditions (e.g., increasing $\mathrm{O}_{2}$ content), which can potentially favour the $\mathrm{N}$ mineralization under enriched $\mathrm{CO}_{2}$ (Wienhold and Halvorson, 1999; Bardgett and Wardle, 2010). These findings suggest that $\mathrm{CO}_{2}$ enrichment can stimulate the $\mathrm{N}$ transfer from organic to inorganic forms in managed croplands.

Unlike leaching, the response of nitrification was dependent upon treatment duration (Fig. 3). Nitrification was not changed by short-term treatment, but was significantly reduced by long-term $\mathrm{CO}_{2}$ enrichment (Fig. 3). One possible reason for the reduced nitrification with long-term $\mathrm{CO}_{2}$ enrichment is the cumulative effect of hydrological changes. $\mathrm{CO}_{2}$ enrichment is assumed to reduce stomatal conductance and, consequently, water loss via plant transpiration, leading to an increase in soil water content (Niklaus et al., 1998; Tricker et al., 2009; van Groenigen et al., 2011; Keenan et al., 2013). A synthesis by van Groenigen et al. (2011) shows that $\mathrm{CO}_{2}$ enrichment increases soil water content by $2.6-10.6 \%$. Increased soil water content may result in less oxygen $\left(\mathrm{O}_{2}\right)$ concentration in soils, which could potentially constrain nitrification.

In addition, the response of gaseous $\mathrm{N}$ loss was dependent on $\mathrm{N}$ addition (Fig. 3). The reduced nitrification was only observed under conditions without $\mathrm{N}$ addition (Fig. 3e). With $\mathrm{N}$ addition, no response of nitrification to $\mathrm{CO}_{2}$ enrichment was observed (Fig. 3e). Additionally, the response of denitrification to $\mathrm{CO}_{2}$ enrichment shifted from neutral, without $\mathrm{N}$ addition, to significantly positive with $\mathrm{N}$ addition (Fig. 3e). One possible reason is that $\mathrm{N}$ addition provides more $\mathrm{N}$ sub- 


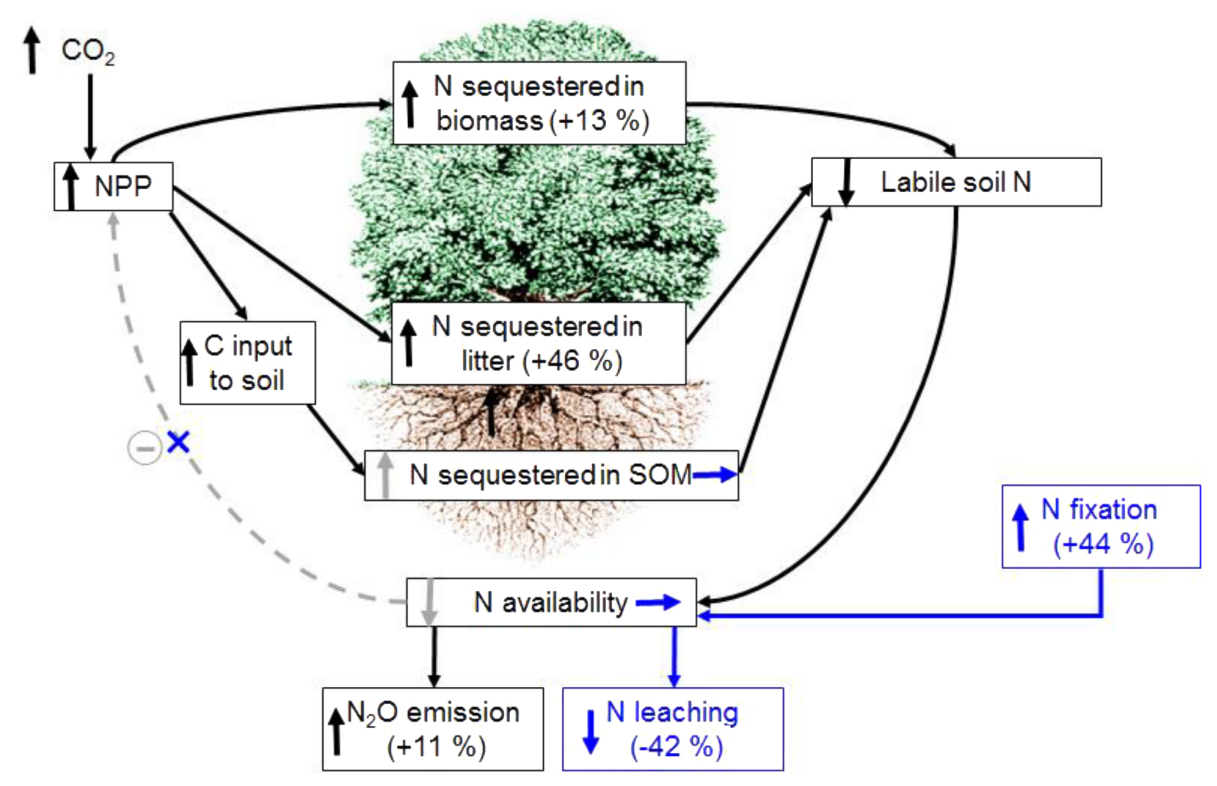

Figure 5. Mechanisms that alleviate PNL. PNL hypothesis posits that the stimulated plant growth by $\mathrm{CO}_{2}$ enrichment leads to more $\mathrm{N}$ sequestered in long-lived plant tissues, litter and soil organic matter (SOM) so that, the $\mathrm{N}$ availability for plant growth progressively declines over time, and plant growth is downregulated (grey symbols). The current synthesis indicates that the basis of PNL occurrence partially exists (i.e., more $\mathrm{N}$ sequestered in plant tissues and litter; black symbols). Despite of the increases in plant $\mathrm{N}$ sequestration and $\mathrm{N}_{2} \mathrm{O}$ emission, stimulated biological $\mathrm{N}$ fixation and reduced $\mathrm{N}$ leaching can replenish the $\mathrm{N}$ availability, potentially alleviating PNL (blue boxes and arrows). Upward, downward, and horizontal arrows mean increase, decrease, and no change, respectively.

strate for nitrifying and denitrifying bacteria (Keller et al., 1988; Stehfest and Bouwman, 2006; Russow et al., 2008). The strengthening trends of both nitrification and denitrification led to a shift of the response of $\mathrm{N}_{2} \mathrm{O}$ emission to $\mathrm{CO}_{2}$ enrichment from neutral without $\mathrm{N}$ addition to significantly positive with $\mathrm{N}$ addition (Fig. 3e). Our results indicate that $\mathrm{CO}_{2}$ enrichment significantly increases gaseous $\mathrm{N}$ loss when additional $\mathrm{N}$ is applied. This is consistent with a previous synthesis (van Groenigen et al., 2011). Increased $\mathrm{N}_{2} \mathrm{O}$ emissions can partially offset the mitigation of climate change by the stimulated plant $\mathrm{CO}_{2}$ assimilation as the warming potential of $\mathrm{N}_{2} \mathrm{O}$ is 296 times that of $\mathrm{CO}_{2}$. However, a recent modelling study by Zaehle et al. (2011) found an opposite result showing that $\mathrm{CO}_{2}$ enrichment reduced emissions of $\mathrm{N}_{2} \mathrm{O}$. In their model, elevated $\mathrm{CO}_{2}$ enhanced plant $\mathrm{N}$ sequestration and consequently, decreased the $\mathrm{N}$ availability for nitrification and denitrification in soils, which led to the reduced $\mathrm{N}_{2} \mathrm{O}$ emissions. However, our synthesis shows that inorganic $\mathrm{N}$ does not decrease. Especially with additional $\mathrm{N}$ application, enhanced denitrification by $\mathrm{CO}_{2}$ enrichment results in a greater $\mathrm{N}_{2} \mathrm{O}$ emission.

\subsection{Changes in soil microenvironment, community structures and above-belowground interactions}

The meta-analysis showed that the two major forms of soil available $\mathrm{N}, \mathrm{NH}_{4}^{+}$and $\mathrm{NO}_{3}^{-}$, responded to long-term $\mathrm{CO}_{2}$ enrichment in opposing manners (Fig. 3c). While the enhanced biological $\mathrm{N}$ fixation by $\mathrm{CO}_{2}$ enrichment tended to increase the $\mathrm{NH}_{4}^{+}$content in soils, the reduced nitrification decreased the $\mathrm{NO}_{3}^{-}$content in soils, leading to a significant increase in the $\mathrm{NH}_{4}^{+} / \mathrm{NO}_{3}^{-}$ratio (Fig. 3c).

Although the total available $\mathrm{N}$ did not change under elevated $\mathrm{CO}_{2}$, the altered proportion of $\mathrm{NH}_{4}^{+}$over $\mathrm{NO}_{3}^{-}$in soils may have long-term effects on soil microenvironment and associated aboveground-belowground linkages that control the $\mathrm{C}$ cycle (Bardgett and Wardle, 2010). On the one hand, plants would release more hydrogen ion $\left(\mathrm{H}^{+}\right)$to regulate the charge balance when taking up more $\mathrm{NH}_{4}^{+}$. As a result, the increased $\mathrm{NH}_{4}^{+}$absorption could acidify the rhizosphere soil (Thomson et al., 1993; Monsant et al., 2008). The lowered $\mathrm{pH}$ could have significant effects on soil microbial communities and their associated ecosystem functions. For example, fungal/bacterial ratio increases with the decrease in pH (de Vries et al., 2006; Rousk et al., 2009). The increased fungal/bacterial ratio may result in lower $\mathrm{N}$ mineralization because of the higher $\mathrm{C} / \mathrm{N}$ ratio of fungi and the lower turnover rates of fungal-feeding fauna (de Vries et al., 2006; Rousk and Bååth, 2007). In other words, the increased fungal/bacterial ratio may slow down the $\mathrm{N}$ turnover from organic to inorganic forms. On the other hand, the increased $\mathrm{NH}_{4}^{+} / \mathrm{NO}_{3}^{-}$ratio may increase the $\mathrm{N}$ use efficiency because it is more energetically expensive for plants to utilize $\mathrm{NO}_{3}^{-}$than $\mathrm{NH}_{4}^{+}$(Chapin III et al., 2011; Odum and Barrett, 2005; Lambers et al., 2008). In addition, since the prefer- 
ences for plant absorption of different forms of $\mathrm{N}$ are different (Chapin III et al., 2011; Odum and Barrett, 2005), the increased $\mathrm{NH}_{4}^{+} / \mathrm{NO}_{3}^{-}$ratio may benefit some plant species while depress others, and consequently alter the community structures over time. These diverse changes in soil microenvironment and microbial and plant community compositions could further affect the terrestrial $\mathrm{C}$ cycle on long temporal scales, on which more studies are needed.

\section{Summary}

This study synthesizes data in the literature on the effects of $\mathrm{CO}_{2}$ enrichment on the terrestrial $\mathrm{N}$ cycle to improve our understanding of the $\mathrm{N}$ limitation to plant growth under elevated $\mathrm{CO}_{2}$. Our results indicate that elevated $\mathrm{CO}_{2}$ stimulates $\mathrm{N}$ influx via biological $\mathrm{N}$ fixation but reduces $\mathrm{N}$ loss via leaching, leading to increased $\mathrm{N}$ supply for plant growth. The additional $\mathrm{N}$ supply via the enhanced biological $\mathrm{N}$ fixation and the reduced leaching may partially meet the increased $\mathrm{N}$ demand under elevated $\mathrm{CO}_{2}$, potentially alleviating PNL. In addition, our analysis indicates that increased $\mathrm{N}_{2} \mathrm{O}$ emissions may partially offset the mitigation of climate change by stimulated plant $\mathrm{CO}_{2}$ assimilation. Moreover, changes in soil microenvironments, ecosystem communities and abovebelowground interactions induced by the different responses of $\mathrm{NH}_{4}^{+}$and $\mathrm{NO}_{3}^{-}$to $\mathrm{CO}_{2}$ enrichment may have long-term effects on the terrestrial biogeochemical cycles and climate change.

\section{The Supplement related to this article is available online at doi:10.5194/bg-13-2689-2016-supplement.}

Acknowledgements. We thank two anonymous reviewers for their valuable comments and suggestions, Kevin R. Wilcox for his help with language checking. This study was financially supported by the US Department of Energy, Terrestrial Ecosystem Sciences grant DE SC0008270 and Biological Systems Research on the Role of Microbial Communities in Carbon Cycling Program grants DE-SC0004601 and DE-SC0010715. Authors declare no conflict of interest.

Edited by: A. Rammig

\section{References}

Asner, G. P., Townsend, A. R., Riley, W. J., Matson, P. A., Neff, J. C., and Cleveland, C. C.: Physical and biogeochemical controls over terrestrial ecosystem responses to nitrogen deposition, Biogeochemistry, 54, 1-39, 2001.

Bardgett, R. D. and Wardle, D. A.: Aboveground-belowground linkages: biotic interactions, ecosystem processes, and global change, Oxford University Press, Oxford, UK, 2010.
Barrios, E., Buresh, R. J., and Sprent, J. I.: Nitrogen mineralization in density fractions of soil organic matter from maize and legume cropping systems, Soil Biol. Biochem., 28, 1459-1465, 1996.

Batterman, S. A., Hedin, L. O., van Breugel, M., Ransijn, J., Craven, D. J., and Hall, J. S.: Key role of symbiotic dinitrogen fixation in tropical forest secondary succession, Nature, 502, 224-227, 2013.

Booth, M. S., Stark, J. M., and Rastetter, E.: Controls on nitrogen cycling in terrestrial ecosystems: A synthetic analysis of literature data, Ecol. Monogr., 75, 139-157, 2005.

Cabrerizo, P. M., González, E. M., Aparicio-Tejo, P. M., and ArreseIgor, $\mathrm{C}$.: Continuous $\mathrm{CO}_{2}$ enrichment leads to increased nodule biomass, carbon availability to nodules and activity of carbonmetabolising enzymes but does not enhance specific nitrogen fixation in pea, Physiologia Plantarum, 113, 33-40, 2001.

Chapin III, F. S., Matson, P. A., and Vitousek, P.: Principles of terrestrial ecosystem ecology, Springer, New York, USA, 2011.

Cleveland, C. C., Townsend, A. R., Schimel, D. S., Fisher, H., Howarth, R. W., Hedin, L. O., Perakis, S. S., Latty, E. F., Von Fischer, J. C., Elseroad, A., and Wasson, M. F.: Global patterns of terrestrial biological nitrogen $\left(\mathrm{N}_{2}\right)$ fixation in natural ecosystems, Global Biogeochem. Cy., 13, 623-645, 1999.

de Graaff, M. A., van Groenigen, K. J., Six, J., Hungate, B., and van Kessel, C.: Interactions between plant growth and soil nutrient cycling under elevated $\mathrm{CO}_{2}$ : a meta-analysis, Glob. Change Biol., 12, 2077-2091, 2006.

de Vries, F. T., Hoffland, E., van Eekeren, N., Brussaard, L., and Bloem, J.: Fungal/bacterial ratios in grasslands with contrasting nitrogen management, Soil Biol. Biochem., 38, 2092-2103, 2006.

Finzi, A. C., Moore, D. J. P., Delucia, E. H., Lichter, J., Hofmockel, K. S., Jackson, R. B., Kim, H., Matamala, R., McCarthy, H. R., Oren, R., Pippen, J. S., and Schlesinger, W. H.: Progressive nitrogen limitation of ecosystem processes under elevated $\mathrm{CO}_{2}$ in a warm-temperate forest, Ecology, 87, 15-25, 2006.

Galloway, J. N., Dentener, F. J., Capone, D. G., Boyer, E. W., Howarth, R. W., Seitzinger, S. P., Asner, G. P., Cleveland, C. C., Green, P. A., Holland, E. A., and Karl, D. M.: Nitrogen cycles: past, present, and future, Biogeochemistry, 70, 53-226, 2004.

Hedges, L. V., Gurevitch, J., and Curtis, P. S.: The meta-analysis of response ratios in experimental ecology, Ecology, 80, 1150$1156,1999$.

Hoque, M. M., Inubushi, K., Miura, S., Kobayashi, K., Kim, H. Y., Okada, M., and Yabashi, S.: Biological dinitrogen fixation and soil microbial biomass carbon as influenced by free-air carbon dioxide enrichment (FACE) at three levels of nitrogen fertilization in a paddy field, Biol. Fert. Soils, 34, 453-459, 2001.

Hunt, S. and Layzell, D. B.: Gas exchange of legume nodules and the regulation of nitrogenase activity, Annu. Rev. Plant Phys., 44, 483-511, 1993.

IPCC: Climate Change 2013: The Physical Science Basis. Contribution of Working Group I to the Fifth Assessment Report of the Intergovernmental Panel on Climate Change, Cambridge University Press, Cambridge, United Kingdom and New York, NY, USA, 2013.

Iversen, C. M.: Digging deeper: fine-root responses to rising atmospheric $\mathrm{CO}_{2}$ concentration in forested ecosystems, New Phytol., 186, 346-357, 2010. 
Keenan, T. F., Hollinger, D. Y., Bohrer, G., Dragoni, D., Munger, J. W., Schmid, H. P., and Richardson, A. D.: Increase in forest water-use efficiency as atmospheric carbon dioxide concentrations rise, Nature, 499, 324-327, 2013.

Keller, M., Kaplan, W. A., Wofsy, S. C., and Dacosta, J. M.: Emissions of $\mathrm{N}_{2} \mathrm{O}$ from Tropical Forest Soils: Response to Fertilization with $\mathrm{NH}_{4}^{+}, \mathrm{NO}^{-}$, and $\mathrm{PO}_{4}^{3-}$, J. Geophys. Res.-Atmos., 93, 1600-1604, 1988.

Lambers, H., Chapin III, F. S., and Pons, T. L.: Plant Physiological Ecology, Springer, New York, 2008.

Liang, J., Xia, J., Liu, L., and Wan, S.: Global patterns of the responses of leaf-level photosynthesis and respiration in terrestrial plants to experimental warming, J. Plant Ecol., 6, 437-447, 2013.

Lu, M., Yang, Y. H., Luo, Y. Q., Fang, C. M., Zhou, X. H., Chen, J. K., Yang, X., and Li, B.: Responses of ecosystem nitrogen cycle to nitrogen addition: a meta-analysis, New Phytol., 189, 10401050, 2011.

Luo, Y. and Reynolds, J. F.: Validity of extrapolating field $\mathrm{CO}_{2}$ experiments to predict carbon sequestration in natural ecosystems, Ecology, 80, 1568-1583, 1999.

Luo, Y., Su, B., Currie, W. S., Dukes, J. S., Finzi, A. C., Hartwig, U., Hungate, B., McMurtrie, R. E., Oren, R., Parton, W. J., Pataki, D. E., Shaw, M. R., Zak, D. R., and Field, C. B.: Progressive nitrogen limitation of ecosystem responses to rising atmospheric carbon dioxide, Bioscience, 54, 731-739, 2004.

Luo, Y. Q., Hui, D. F., and Zhang, D. Q.: Elevated $\mathrm{CO}_{2}$ stimulates net accumulations of carbon and nitrogen in land ecosystems: A meta-analysis, Ecology, 87, 53-63, 2006.

McCarthy, H. R., Oren, R., Johnsen, K. H., Gallet-Budynek, A., Pritchard, S. G., Cook, C. W., LaDeau, S. L., Jackson, R. B., and Finzi, A. C.: Re-assessment of plant carbon dynamics at the Duke free-air $\mathrm{CO}_{2}$ enrichment site: interactions of atmospheric $\left[\mathrm{CO}_{2}\right]$ with nitrogen and water availability over stand development, New Phytol., 185, 514-528, 2010.

Monsant, A. C., Tang, C., and Baker, A. J. M.: The effect of nitrogen form on rhizosphere soil $\mathrm{pH}$ and zinc phytoextraction by Thlaspi caerulescens, Chemosphere, 73, 635-642, 2008.

Moore, D. J. P., Aref, S., Ho, R. M., Pippen, J. S., Hamilton, J. G., de Lucia, E. H.: Annual basal area increment and growth duration of Pinus taeda in response to eight years of free-air carbon dioxide enrichment, Glob. Change Biol., 12, 1367-1377, 2006.

Niklaus, P. A., Spinnler, D., and Korner, C.: Soil moisture dynamics of calcareous grassland under elevated $\mathrm{CO}_{2}$, Oecologia, 117 , 201-208, 1998.

Norby, R. J., Long, T. M., Hartz-Rubin, J. S., and O’Neill, E. G.: Nitrogen resorption in senescing tree leaves in a warmer, $\mathrm{CO}_{2}$ enriched atmosephere, Plant Soil, 224, 15-29, 2000.

Norby, R. J., Cotrufo, M. F., Ineson, P., O’Neill, E. G., and Canadell, J. G.: Elevated $\mathrm{CO}_{2}$, litter chemistry, and decomposition: a synthesis, Oecologia, 127, 153-165, 2001.

Norby, R. J., Warren, J. M., Iversen, C. M., Medlyn, B. E., and McMurtrie, R. E.: $\mathrm{CO}_{2}$ enhancement of forest productivity constrained by limited nitrogen availability, P. Natl. Acad. Sci. USA, 107, 19368-19373, 2010.

Odum, E. P. and Barrett, G. W.: Fundamentals of Ecology, Thomson Brooks/Cole, Belmont, California, USA, 2005.

Oren, R., Ellsworth, D. S., Johnsen, K. H., Phillips, N., Ewers, B. E., Maier, C., Schafer, K. V. R., McCarthy, H., Hendrey, G., McNulty, S. G., and Katul, G. G.: Soil fertility limits carbon se- questration by forest ecosystems in a $\mathrm{CO}_{2}$-enriched atmosphere, Nature, 411, 469-472, 2001.

Poorter, H. and Navas, M. L.: Plant growth and competition at elevated $\mathrm{CO}_{2}$ : on winners, losers and functional groups, New Phytol., 157, 175-198, 2003.

Rastetter, E. B., Agren, G. I., and Shaver, G. R.: Responses of $\mathrm{N}$-limited ecosystems to increased $\mathrm{CO}_{2}$ : A balanced-nutrition, coupled-element-cycles model, Ecol. Appl., 7, 444-460, 1997.

Reay, D. S., Dentener, F., Smith, P., Grace, J., and Feely, R. A.: Global nitrogen deposition and carbon sinks, Nat. Geosci., 1, 430-437, 2008.

Reich, P. B. and Hobbie, S. E.: Decade-long soil nitrogen constraint on the $\mathrm{CO}_{2}$ fertilization of plant biomass, Nature Climate Change, 3, 278-282, 2013.

Reich, P. B., Hobbie, S. E., Lee, T., Ellsworth, D. S., West, J. B., Tilman, D., Knops, J. M. H., Naeem, S., and Trost, J.: Nitrogen limitation constrains sustainability of ecosystem response to $\mathrm{CO}_{2}$, Nature, 440, 922-925, 2006.

Rosenberg, M. S., Adams, D. C., and Gurevitch, J.: MetaWin: statistical software for meta-analysis, Sinauer Associates Sunderland, Massachusetts, USA, 2000.

Ross, D. J., Newton, P. C. D., Tate, K. R., and Luo, D. W.: Impact of a low level of $\mathrm{CO}_{2}$ enrichment on soil carbon and nitrogen pools and mineralization rates over ten years in a seasonally dry, grazed pasture, Soil Biol. Biochem., 58, 265-274, 2013.

Rousk, J. and Bååth, E.: Fungal biomass production and turnover in soil estimated using the acetate-in-ergosterol technique, Soil Biol. Biochem., 39, 2173-2177, 2007.

Rousk, J., Brookes, P. C., and Baath, E.: Contrasting Soil pH Effects on Fungal and Bacterial Growth Suggest Functional Redundancy in Carbon Mineralization, Appl. Environ. Microb., 75, 1589-1596, 2009.

Russow, R., Spott, O., and Stange, C. F.: Evaluation of nitrate and ammonium as sources of $\mathrm{NO}$ and $\mathrm{N}_{2} \mathrm{O}$ emissions from black earth soils (Haplic Chernozem) based on ${ }^{15} \mathrm{~N}$ field experiments, Soil Biol. Biochem., 40, 380-391, 2008.

Schneider, M. K., Luscher, A., Richter, M., Aeschlimann, U., Hartwig, U. A., Blum, H., Frossard, E., and Nosberger, J.: Ten years of free-air $\mathrm{CO}_{2}$ enrichment altered the mobilization of $\mathrm{N}$ from soil in Lolium perenne L. swards, Glob. Change Biol., 10, 1377-1388, 2004.

Smith, S. D., Charlet, T. N., Zitzer, S. F., Abella, S. R., Vanier, C. H., and Huxman, T. E.: Long-term response of a Mojave Desert winter annual plant community to a whole-ecosystem atmospheric $\mathrm{CO}_{2}$ manipulation (FACE), Glob. Change Biol., 20, 879-892, 2014.

Stehfest, E. and Bouwman, L.: $\mathrm{N}_{2} \mathrm{O}$ and $\mathrm{NO}$ emission from agricultural fields and soils under natural vegetation: summarizing available measurement data and modeling of global annual emissions, Nutr. Cycl. Agroecosys., 74, 207-228, 2006.

Talhelm, A. F., Pregitzer, K. S., and Giardina, C. P.: Long-Term Leaf Production Response to Elevated Atmospheric Carbon Dioxide and Tropospheric Ozone, Ecosystems, 15, 71-82, 2012.

Thomson, C. J., Marschner, H., and Romheld, V.: Effect of Nitrogen-Fertilizer Form on $\mathrm{pH}$ of the Bulk Soil and Rhizosphere, and on the Growth, Phosphorus, and Micronutrient Uptake of Bean, J. Plant Nutr., 16, 493-506, 1993.

Tricker, P. J., Pecchiari, M., Bunn, S. M., Vaccari, F. P., Peressotti, A., Miglietta, F., and Taylor, G.: Water use of a bioenergy plan- 
tation increases in a future high $\mathrm{CO}_{2}$ world, Biomass Bioenerg., 33, 200-208, 2009.

Tu, Q., Zhou, X., He, Z., Xue, K., Wu, L., Reich, P., Hobbie, S., and Zhou, J.: The Diversity and Co-occurrence Patterns of $\mathrm{N}_{2}$-Fixing Communities in a $\mathrm{CO}_{2}$-Enriched Grassland Ecosystem, Microb. Ecol., 71, 604-615, doi:10.1007/s00248-015-0659-7, 2016.

van Groenigen, K. J., Osenberg, C. W., and Hungate, B. A.: Increased soil emissions of potent greenhouse gases under increased atmospheric $\mathrm{CO}_{2}$, Nature, 475, 214-216, 2011.
Walker, A. P., Zaehle, S., Medlyn, B. E., De Kauwe, M. G., Asao, S., Hickler, T., Parton, W., Ricciuto, D. M., Wang, Y. P., and Wårlind, D.: Predicting long-term carbon sequestration in response to $\mathrm{CO}_{2}$ enrichment: How and why do current ecosystem models differ?, Global Biogeochem. Cy., 29, 476-495, 2015.

Wienhold, B. J. and Halvorson, A. D.: Nitrogen mineralization responses to cropping, tillage, and nitrogen rate in the Northern Great Plains, Soil Sci. Soc. Am. J., 63, 192-196, 1999.

Zaehle, S., Ciais, P., Friend, A. D., and Prieur, V.: Carbon benefits of anthropogenic reactive nitrogen offset by nitrous oxide emissions, Nat. Geosci., 4, 601-605, 2011. 